\title{
TITLE:
}

\section{$<$ Note> Rejecting a Bit of Meat to Get More}

$\operatorname{AUTHOR}(S):$

\author{
Zamma, Koichiro
}

\section{CITATION:}

Zamma, Koichiro. < Note> Rejecting a Bit of Meat to Get More. Pan Africa News 2005, 12(1): 8-10

\section{ISSUE DATE:}

2005-06

URL:

http://hdl.handle.net/2433/143449

RIGHT:

Copyright (C) Pan Africa News. 
$<$ NOTE $>$

\section{Rejecting a Bit of Meat to Get More}

Koichiro Zamma

Primate Research Institute, Kyoto University

\section{INTRODUCTION}

"A variety of interactions involving interindividual transfer of possession of food items occurs along a spectrum approximating degrees of volition ${ }^{1}$, food sharing is one interesting behavior among chimpanzees. I will present a case study in which a wild infant chimpanzee rejected a small piece of meat offered by her mother. Infants learn about many kind of foods they cannot process by themselves ${ }^{2}$. However, shared foods are not always good. In captivity chimpanzee mothers 
have been observed to offer only unpalatable parts to their infants when they initiate the sharing ${ }^{3}$. Can infants obtain desirable foods when offered undesirable ones? Here I will show a possible case of flexible negotiation between a possessor and a non-possessor.

\section{RESULTS}

Phase 1: reluctant acceptance. I conducted research on grooming among chimpanzee infants in the M Group at Mahale Mountains National Park, Tanzania, from May to July, 2004. On June 30 , at 11:28, Kalunde, an old male, caught a red colobus. At 13:17, Fatuma, an old female, held and ate a chunk of this colobus meat transferred by Kalunde. Fatuma had two female infants, Flavia (5 yrs) and FT03 (1 yr). Flavia was eating a piece of meat at a distance of 1 meter from Fatuma. At 13:18, Flavia whimpered and extended her left hand to Fatuma. Fatuma stopped eating and held the rest of the chunk of meat in her left hand, and then started to approach Flavia. Flavia put her hand on the meat, but Fatuma twisted her left wrist free of Flavia's hand. Fatuma continued to approach, showing Flavia a bit of meat, roughly $1 \mathrm{~cm}^{3}$, between her lips and fed it to Flavia mouth to mouth. Flavia chewed it. Fatuma put the chunk into her mouth. Flavia whimpered again and reached for Fatuma's mouth. When Flavia gave a noisy whimpering scream, Fatuma embraced Flavia. However, Flavia continued to whimper and touch her mother's mouth. After Fatuma started to groom the head of Flavia, as if trying to divert Flavia's eyes from the chunk, Flavia stopped whimpering and chewed the bit of meat again.

Phase 2: rejecting a bit of meat. A quarter hour after phase 1, Flavia again solicited a chunk of meat held by Fatuma. At 13:34, Fatuma showed a bit of meat between her lips and offered it to Flavia. However, Flavia rejected it. Fatuma groomed Flavia. At 13:35, Flavia ate a chunk of meat held by Fatuma. Fatuma also ate the opposite end of it without paying attention to Flavia.

Phase 3: object gained, meat lost. Fatuma continued to hold the chunk of meat. Flavia solicited the chunk of meat, as in phases 1 and 2 until 14:23. At 14:24, Flavia solicited and took the chunk, which resembled a piece of fur. Flavia put the fur into her mouth and chewed it until 14:39, after which I lost track of them.

\section{DISCUSSION}

Rejecting offered food among wild chimpanzees has not been reported, as far as I know, and I have observed it only once in my research. Why did Flavia reject a bit of meat, even though she solicited it? Flavia was five years old, which is mature enough to know that meat is good food, and she had already been eating some bits of meat before rejecting it. However, the rate of meat intake was low. So, Flavia wanted more meat in a short time and asked for the chunk of meat held by Fatuma. In phase 1, Flavia was compelled to accept the offer, a bit of meat, from her mother. In phase 2, Flavia rejected the bit of meat, continued her solicitation, and succeeded in eating the chunk of meat. Though a scrap of meat is still meat, it may mean little for a growing infant.

Why did Fatuma offer a bit of meat? She seemed skillful in calming her whimpering daughter. It is not that she refused absolutely Flavia's solicitation. Fatuma agreed to the request for meat but only a little bit. If Flavia compromised on just a little quantity of meat, Fatuma could eat more meat. Grooming also helped to divert Flavia's attention from the chunk of meat (phase 1).

Food is not always distributed equally even if a possessor divides, offers, and shares it. A possessor occasionally offers not only an unpalatable part of food $^{3}$ but also a small amount of food. If a non-possessor solicits and steals meat, the non-possessor can eat as much as possible. However, when a possessor divides meat, the possessor can control it for selfish ends. Fatuma divided the meat into two unequal pieces and used two food sharing tactics: not to tolerate the solicitation for a chunk and to offer a smaller piece. Flavia used two other tactics: refusing to accept the offer and continuing solicitation for a larger piece (phase 2). In the end, Flavia ate the chunk of meat. However, the meat might decrease in value for the possessor, Fatuma, after she had eaten more of it ${ }^{4}$. It is difficult to decide whether the negotiation really lowered the threshold of resistance of Fatuma.

\section{REFERENCES}

1. McGrew WC. 1975. Patterns of plant food sharing by wild chimpanzees. In: Kondo S, Kawai M, Ehara A (eds), Contemporary Primatology, Karger, Basel, pp 304-309.

2. Nishida T, Turner LA. 1996. Food transfer between mother and infant chimpanzees of the Mahale Mountains National Park, Tanzania. Int. J. Primatol. 17: 947-968.

3. Ueno A, Matsuzawa T. 2004. Food transfer between 
chimpanzee mothers and their infants. Primates 45 : 231-239.

4. Feistner ATC and McGrew WC. 1989. Food-sharing in primates: a critical review. In: Seth PK, Seth S (eds), Perspectives in primate biology, vol. 3, Today $\&$ Tomorrow's Printers and Publishers, New Delhi, pp 21-36. 